\title{
PERCEPTION OF EXTERNAL STAKEHOLDERS ON THE AVAILABILITY OF THE LACTATION CORNER ACCORDING TO THE REGULATION OF THE MINISTER OF HEALTH NO 15/2013 CONCERNING THE PROVISION OF SPECIAL FACILITIES FOR BREASTFEEDING IN THE MALL OF TEGAL CITY
}

\author{
Evi Zulfiana ${ }^{1)}$, Seventina Nurul Hidayah ${ }^{2)}$ \\ Email : evi.zulfiana33@gmail.com \\ 1,2Program Studi D III Kebidanan Politeknik Harapan Bersama \\ J1.Mataram no.09 Pesurungan Lor Kota Tegal
}

Article Information

Received:

September 27, 2019

Revised:

December 26, 2019

Accepted:

January 19, 2020

Available online:

January 23, 2020

\section{Abstract}

Based on the Regulation of the Ministry of Health No. 15/2013, an institution or public places must provide particular facilities for breastfeeding mothers. Therefore, stakeholders must be able to guarantee the availability of space for the comfort and freedom of mothers in breastfeeding their children. The purpose of this study was to determine the perceptions of external stakeholders about the existence, constraints, and lactation corner policies. This study was qualitative. Data retrieval was carried out with in-depth interview techniques using interview guidelines. The results of the information obtained were recorded. The data obtained validated using source triangulation. The results of this study found that all respondents had perceptions about breast milk and lactation corners correctly. Constraints on the use of lactation corners found that there was no refrigerator in the mall. The majority of respondents do not understand that there was a policy that regulates the existence of the lactation corner; it was due to the lack of socialization to stakeholders from related parties.

Keyword: Breastfeeding, Lactation Corner, mall, stakeholders

\section{Introduction}

Exclusive breastfeeding is breast milk that is given to babies from birth for six months without adding and replacing with other food or drinks. During this process, the regional government needs to support the provision of individual facilities and time entirely ${ }^{[1]}$.

The existence of particular facilities in the workplace and public facilities is regulated in the Regulation of the Ministry of Health No. 15/ 2013 concerning Procedures for Providing Special Facilities for Breastfeeding and Expressing Breast Milk. The mall as one of the public service facilities; a gathering place for many people, including female employees and female visitors who were breastfeeding their children and needed a lactation corner. Therefore, the role of stakeholders is crucial in achieving the success of exclusive breastfeeding programs. For this reason, stakeholders must be able to guarantee the availability of space for the comfort and freedom of mothers in breastfeeding their children. ${ }^{[2]}$

Based on the data from SDKI in 2017, the percentage of children under the age of 6 months who received exclusive breastfeeding increased in the last five years, from $42 \%$ to $52 \%$. The percentage of children who were not breastfed rose from $8 \%$ to $12 \%$. This figure identifies that there were few children in the archipelago who get 
enough nutrition from breast milk, while breast milk is essential in the process of growth and development of babies both physically and mentally with long-term consequences. $^{[3]}$

Republic of Indonesia Government Regulation No. 33 / 2012 stated that every mother giving birth is required to give exclusive breastfeeding to babies born until the age of 6 months; because exclusive breastfeeding can increase the status nutrition of infants and children and affect the subsequent health status. ${ }^{[4]}$

Based on the data obtained, the exclusive breastfeeding coverage in Tegal City in 2013 was $49.55 \%$, an increase compared to 2012, which was $38.89 \%$. It was still below the expected national coverage of $80 \%$. The highest 6 month breastfeeding coverage was in the West Tegal Health Center area of $66.7 \%$, but the coverage was still below the national coverage. ${ }^{[5]}$

The role of stakeholders in the mall is beneficial for the success of the exclusive breastfeeding program. The success of the program can be seen from the provision of protection for breastfeeding mothers by stakeholders. One form of protection referred to the provision of a lactation corner. Many malls in Tegal city did not have particular facilities for nursing mothers; this can lead to different perceptions among external stakeholders ${ }^{[6]}$. External stakeholders are stakeholders from outside the mall, namely consumers. Not all consumers knew in general about the lactation corner, so consumers have different perceptions about the lactation corner facility.

A study conducted by Handayani (2011) found that perceptions of barriers heavily influence the comparison of breastfeeding mothers with exclusive breastfeeding and breastfeeding mothers with non-exclusive breastfeeding. Some breastfeeding mothers said that the problem was related to the provision of lactation corner that was less supportive because the presence of lactation corner will indirectly have an impact on comfort while in public places - even the attitude of breastfeeding mothers considered to play a role in this difference. The mother's knowledge factor also influences the success of the practice of exclusive breastfeeding. ${ }^{[7]}$

Preliminary studies conducted in three malls in Tegal city found only one mall that provides lactation corner facilities, but the infrastructure provided was still inadequate. Until now, there had not been an evaluation for external perception about regulation on the availability of lactation corner. The purpose of this study was to determine the perceptions of external stakeholders about the lactation corner, lactation corner constraints, lactation corner policy.

\section{Method}

The study was conducted at the Transmart Mall in August 2019. This study used a qualitative method. Samples were taken by purposive sampling, referring to the purpose and type of research. The informants in this study consisted of the main informants and triangulation. The main informants were external stakeholders, namely consumers who visit the mall who have babies under six months of age and only give breast milk and obtained as many as four informants. The triangulation information in this study was the head of the Department of Civil Transmart Mall Tegal City and the Section Head of nutrition improvement Tegal City health department community. Data were collected by in-depth interview technique using interview guidelines. Data collected included the existence of lactation corner at Transmart Mall, general knowledge about breastfeeding for six months, general knowledge about breastfeeding corner, obstacles encountered in using lactation corner, knowledge of legal sanctions, implementation of socialization of lactation corner provision and related problem-solving barriers experienced by mothers to give exclusive breastfeeding. The results of the interviews were recorded, and field notes were made. To 
prevent subjectivity, the data being validated using source triangulation techniques. ${ }^{[8]}$

\section{Results and Discussion}

The Transmart Mall in Tegal City is located on $546^{\text {th }}$, Colonel Sugiono Street, Tegal City. It had three floors. Transmart is also a centre for shopping, dining, playing and watching movies. The breastfeeding room at Transmart has been around since 2017 and is still used until today. This room is used by mall visitors when they want to breastfeed or change diapers. The available facilities are tables, chairs and tables for changing diapers.

a. Perception about Breastfeeding and Lactation Corner

The results showed that the majority of informants understood general knowledge about exclusive breastfeedings, such as the benefits of breastfeeding. Breast milk is the best food for babies, endurance or body resistance, digestive health, intelligence, increasing mother-child bonding, and it is more practical.

"Breast Milk is baby food, the benefits of which are to increase the baby's immunity, so that his digestion is healthy, for intelligence, to strengthen the relationship between mother and child and more practical if exclusive breastfeeding means giving milk until six months do not use new food." (1 $1^{\text {st }}$ Informant)

"Breast milk is the best food for children to be given from the age of 0-6 months, more practical, not complicated." ( $2^{\text {nd }}$ Informant)

"Breast milk is an important food for the baby to protect the baby's immune." (3 ${ }^{\text {rd }}$ Informant $)$

"Breast milk is good for baby growth." (4 $4^{\text {th }}$ Inforrmant)

Also, the informant understood that in giving exclusive breastfeeding what needs to be considered was the time of delivery. Therefore the existence of husband's support will be beneficial in exclusive breastfeeding.
"Give breast milk as often as possible so that the baby will not become fussy. my husband was very supportive of me giving breast milk" ( $1^{\text {st }}$ Informan)

The informant's knowledge about lactation corner was sufficient. The informant was able to explain what is meant by the lactation corner and the need for its existence.

"Lactation corner, if I am not mistaken, it has already arranged in the Minister of Health's regulation. Every office or mall should have a lactation/nursing room." $\quad\left(1^{\text {st }}\right.$ Informan).

"A lactation corner is a place for breastfeeding mothers. There were in malls. Also, there might be in offices or other institutions." ( $2^{\text {nd }}$ Informant)

"The lactation corner at the mall was good for those who want to breastfeed because it was ashamed if you have to feed in a crowded place. It was also used for changing diapers when the baby poop." ( $3^{\text {rd }}$ Informant) "There must be a lactation corner, especially the shopping mall." $\left(4^{\text {th }}\right.$ Informant)

b. Constraints on the Use of a Lactation Corner

Based on the results of the interview, the informant felt the benefits of the lactation corner existence, but in its uses, the informant encountered obstacles, especially for mothers who milked breast milk. The lactation corner room does not have a refrigerator or freezer that can be used to store breast milk.

"I was hoped that every lactation corner had a refrigerator. The thing is, if I go to the mall right from the workplace, I do not bring my baby, but I usually only milked breast milk. However, here there is no refrigerator, so I kept it in the breast milk bag, so I had to carry it everywhere. However, if possible, there is should at least one refrigerator in the lactation corner." ( $2^{\text {nd }}$ Informant) 
"We do not have a refrigerator in the lactation corner." ( $1^{\text {st }}$ Triangulation Informant)

The unavailability of a refrigerator or freezer in the lactation corner was caused by the mall's lack of knowledge regarding regulations of minimum requirements that must be met for the provision of a lactation corner. The obstacles in implementing government policy were not only influenced by the number of parties involved but also because the process was influenced by various variables that interact with each other. ${ }^{[9,10]}$

Based on the results of in-depth interviews with triangulation informants, they did not understand about the requirements for the provision of lactation space, especially in public places.

"Lactation corner is used to express milk, and I do not understand the detailed requirements in providing breastfeeding space in the Mall as a public facility for visitors, especially breastfeeding mothers." $\quad\left(1^{\text {st }}\right.$ Triangulation Informant).

"Our side is not aware of if there is or that describes the procedure for providing special breastfeeding facilities." $\quad\left(2^{\text {nd }} \quad\right.$ Triangulation Informant)

The required facilities are infrastructure that can facilitate the implementation of a policy. It is used to support directly and is bound to the tasks that have been decided. Physical facilities are a crucial factor in policy implementation. Facilities such as lactation rooms that have been provided by the mall have been able to carry out the lactation corner policy. Based on observations, the physical facilities provided by the mall were only tables, chairs and tables for changing diapers; this shows that the facilities provided were still incomplete. It is necessary to add a refrigerator that can be used by mothers to put their breast milk after milking. ${ }^{[2]}$
In providing a lactation corner, there are minimum requirements that must be met. Minimum space area of $3 \times 4 \mathrm{~m}$; floor using ceramic / cement/carpet. Some doors can be locked, which are easily opened/closed. The room should free of potential hazards, one of which is pollution-free and have adequate ventilation and air circulation. It should have a quiet environment, away from noises; Indoor lighting should be sufficient and not dazzling. The humidity ranges from $30-50 \%$, maximum of $60 \%$. Moreover, there is a sink equipped with running water to wash hands and wash the breastfeeding device. ${ }^{[2]}$

However, in general, informants as consumers were satisfied with the efforts to provide breastfeeding room to maintain the privacy of mothers, especially when breastfeeding or milking. At least when going to change a baby's diaper can also freely replace it in the room. It was just that for visitors who visited the mall and did not bring their babies they can only express milk but can not save their breast milk.

\section{c. Regulation of Lactation Corner}

Data from the informant found that there was a lack of understanding of the regulation which regulates in detail the procurement of lactation corner in public places such as malls. They only knew that there was a Minister of Health regulation, but they admitted that they were still confused about the purpose of the Minister of Health.

"I do not know if there are government regulations that require public places to provide lactation space and have never been found out about the lactation space policy in public places or from the health department." $\left(1^{\text {st }}\right.$ Informant)

"I know from the internet" (2 $2^{\text {nd }}$ Informant)

"I do not know about it" ( $\left.3^{\text {rd Informant }}\right)$ 
"I do not know about it" (4t Informant $)$

"We had not socialized it yet." (1 $1^{\text {st }}$ Triangulation Informant)

"Health office conducted socialization to facilities such as Health centre and Hospitals then the health centre responsible for socialized it to the districts." $\left(2^{\text {nd }}\right.$ Triangulation Informant)

The current policy regarding the need for breastfeeding room had been going on for a long time since 2012. The information had not been distributed properly. It was shown from many informants who did not know about lactation corner regulations in public places. Even though there was much information from the internet, but still, many people did not know about it. Whereas the enactment of this regulation is to support the exclusive breastfeeding program that is given for six months, so that the right of children to get exclusive breastfeeding can be adequately fulfilled and to foster the role of the family and also the surrounding community. ${ }^{[11]}$

The results showed that the existence of a policy in providing breastfeeding room has a positive response from the government, the mall and the community. This is in line with Saputri (2013) that company workers need a particular room for milking. Most female company workers feel distressed, especially when milking during work hours because there was no particular room provided for them. They usually wasted their breast milk in the bathroom. If the company provide this particular room for milking, indirectly they supported the government in achieving breastfeeding coverage. ${ }^{[12]}$

The results of the interview also showed the ineffectiveness of the policy socialization strategy. The information provided tends to be confusing so that the program implementers in implementing it were less than optimal [13]. It can be interpreted that the socialization process of the organizers and also the directives has not been carried out correctly and needs to be improved two-way communication that supports the government program policies achieved to the maximum. ${ }^{[14]}$ Clarity of communication interpreted as the information received by the recipient of the information must be clear and not confusing or ambiguous so that the program can run smoothly. ${ }^{[15]}$

Not only communication which influencing the implementation but also includes other variables such as human resources, materials and other infrastructures such as rules and manuals. Although the contents of the policy had been conveyed clearly and consistently, if the policy implementers lack the resources to implement it, the program implementation will run less effectively. ${ }^{[16]}$

\section{Conclusion}

External stakeholder's perceptions can influence exclusive breastfeeding so that an in-depth understanding of the availability of the lactation corner at the Transmart Mall. All informants have the right perception of breast milk and lactation corner. The obstacle in utilizing the lactation corner was the lack of breast milk storage facilities, especially for mothers who express milk. This is due to the mall's lack of understanding of the regulations regarding the minimum requirements for lactation corner facilities.

The Mall expected to provide a standard operational procedure specifically for the provision of lactation corner, which includes lactation corner standards referring to Minister of Health Regulation No. 15 of 2013 concerning Procedures for Provision of Breastfeeding and Expressing Breast Milk Facilities. There is a need for sanctions imposed if an agency has not provided a space for lactation corner and 
improve the quality and quantity of resources both from human resources and from the facility and other resources.

\section{References}

[1] Weni, Kristiyanasari. ASI, Menyusui \& Sadari. Yogyakarta: Nuha Medika. 2011.

[2] Kementerian Kesehatan Republik Indonesia. Peraturan Menteri Kesehatan Republik Indonesia. Nomor 15 tahun 2013 tentang Tata Cara Penyediaan Fasilitas Khusus Menyusui dan/atau Memerah Air Susu Ibu. Jakarta. Kementerian Kesehatan Republik Indonesia. 2013.

[3] Banglitbangkes Kemenkes RI. Riset Kesehatan Dasar Tahun 2013. Kementerian Kesehatan RI: Jakarta. 2013.

[4] Presiden Republik Indonesia. Peraturan Pemerintah Republik Indonesia Nomor 33 tahun 2012 tentang Pemberian Air Susu Ibu Eksklusif. Jakarta: Kementrian Sekretariat Negara RI. 2012.

[5] Dinas Kesehatan Kota Tegal. Profil Kesehatan Kota Tegal tahun 2013. Tegal: Dinas Kesehatan Kota Tegal. 2014.

[6] Hesti, Widuri. Cara kelola ASI Eksklusif Ibu Bekerja. Yogyakarta: Gosyen Publishing. 2013.

[7] Wulandari \& Handayani. Asuhan kebidanan ibu masa nifas. Yogyakarta: Gosyen Publishing. 2011

[8] Setiawan, Ari dan Saryono. Metodologi Penelitian Kebidanan DIII, DIV, S1 dan S2. Yogyakarta: Nuha Medika. 2012

[9] Wiryanto. Pengantar ilmu komunikasi, Penerbit PT. Gramedia Widiasarana Indonesia. Jakarta: Nuha Medika. 2014.

[10] Budiman, dan Riyanto, A. Pengetahuan dan Sikap Dalam Penelitian Kesehatan. Jakarta: Salemba Medik. 2013.

[11] Wijaya PS, Soesanto SS. Kajian Implementasi Kebijakan Pojok ASI Di Sektor Pemerintah dan
Swasta. Unnes Journal of Public Health. 2017;6(3):196- 202

[12] Dyah Atika Saputri. Analisis pelaksanaan kebijakan ruang menyusui di Mall X Kota Solo. Jurnal kesehatan masyarakat. 2013. Volume 8 Nomor 1.

[13] Abdul Wahab, Solichin. Analisis Kebijakan: dari Formulasi ke Implementasi Kebijakan Negara Edisi Kedua. Jakarta: Bumi Aksara. 2010.

[14] Surbakti, E. Rendahnya Pemberian ASI Eksklusif pada Ibu yang Bekerja Lingkungan XX Kelurahan Kwala Berkala Kecamatan Medan Johor. Jurnal Ilmiah Punmed. 2014. Volume 9 Nomor 1, Mei-Agustus.

[15] Johnson AM, Kirk R, Muzik M. Overcoming workplace barriers: A focus group study exploring African American mothers' needs for workplace breastfeeding support. Journal of Human Lactation. 2015;31(3):425-433

[16] A.G Subarsono. Analisis kebijakan Publik konsep, teori dan Aplikasi. Yogyakarta: Pustaka Pelajar. 2010

[17] Winarno, Budi. Kebijakan Publik. Teori, Proses, dan Studi Kasus. Yogyakarta: CAPS. 2011 